\title{
Retail Investor Attention and Firm Investment Efficiency
}

\author{
Li Jianhong ${ }^{1, a, *, \dagger}$, Sun Zhuoran ${ }^{2, \text { b, }{ }^{*}, \dagger}$, Zhou Qi ${ }^{3, c, *, \dagger}$ \\ ${ }^{1}$ Li Jianhong (Xi'an Jiaotong-liverpool University) \\ ${ }^{2}$ Sun Zhouran (Northeast Agricultural University) \\ ${ }^{3}$ Zhou Qi (Northeast Agricultural University) \\ *Corresponding author.Email: ${ }^{*} 1441979068 @ q q . c o m,{ }^{b} 2009010126 @$ st.btbu.edu.cn, ${ }^{c} 2009010202 @$ st.btbu.edu.cn \\ These authors contributed equally.
}

\begin{abstract}
In this paper, we investigate the impact of retail investor attention on a firm's investment efficiency. We found that retail investor attention is positively associated with a firm's investment efficiency by means of baseline regression. Further analyses show that the impact of retail investor attention is more pronounced in firms with lower social regulation, small market capitalization, non-state-owned, and non-Big 4 auditing. The association is robust to a series of robustness checks, and the results are in line with our expectations. This provides us with a new perspective to measure the return on investment of firms. Therefore, the retail investor attention even has a crucial impact on the company's future governance and corporate decisions.
\end{abstract}

Keywords: Retail investor ; firm investment efficiency

\section{INTRODUCTION}

The increase of firm value fundamentally depends on the firm's investment decision and investment efficiency. The efficiency of investment behavior is directly related to the maximization of firm value. The inefficient investment will lead to the waste of firm resources and damage the interests of investors. So, firms themselves pay attention to investment efficiency and the academic circles generally pay attention to firm investment efficiency. Some existing literature discusses the influence of the internal behavior or condition of the firmon-firm investment efficiency. For instance, the factors that affect the firm investment efficiency include agency problems and information asymmetry [1], Corporate governance [2], Management competence [3], Corporate risk-taking, and executive financial background [4]. Besides, there are also many literatures on the impact of a complex external environment on the firm investment efficiency. For instance, Customer concentration and enterprise investment efficiency [5], Corporate social responsibility and investment efficiency [6], Media attention, and firm investment efficiency [7]. Cen, W. et al. [8] found that institutional investor attention can restrain the inefficient investment behavior of listed firms.
Unlike the above studies, this paper aims to explore the impact of retail investor attention on the firm investment efficiency.

Existing studies have shown that investor attention can significantly affect stock returns $[9,10]$. Meanwhile, in other capital markets, Nayak [11] studied the impact of investor attention on corporate bonds. Simon and Wiggins [12] and Wang [13] studied the impact of investor attention on the stock index futures market. Bahloul, Bouri [14] and studied the impact of investor attention on the commodity futures market. Although some scholars have put forward opposite views, BenRephael [15] and other scholars believe that investor attention positively impacts asset returns. The research of Aissia [16] shows that investors pay attention to the inverse predictor of asset returns. To sum up, investor attention has a far-reaching influence on corporate governance and other aspects. In most countries, especially in developing countries, agency conflicts mainly exist between major investors and retail investors [17]. External retail investors can choose to supervise companies through various means actively. Existing researches on investors are mostly focused on institutional investors, and few scholars have studied retail investors. Although the number of institutional investors in China has gradually increased in recent years, 
individual small and medium investors are still an important participation force in China's secondary market.

Compared to capital markets in more developed or developed countries, the capital market and the financial market in China under the socialist system are very different. It provides us a variable background to measure the retail investor attention and firm investment efficiency. There are several main reasons why we are focusing on the Chinese market. First of all, due to the huge population base, most of the participants in the Chinese financial market and those who invest capital are retail investors Gao, Y. et al. [18] found that more than 60 percent of the investors are retail investors. Therefore, exploring how the retail investor attention affects the firm investment efficiency has significant meaning in the Chinese market. Secondly, Xiao et al. [19] demonstrated that the Chinese financial market structure is not perfect. The main body of the financial market is not mature. We also know that the financial market price is very unstable, with weak supervision and not perfect financial regulation, and there is not a strong binding regulation system, which will catch big attention from retail investors. Therefore, research on the role of retail attention in the Chinese market will help promote the development of the Chinese financial market and further study on the firms in the Chinese market. Finally, since the reform and opening up, the Chinese financial market has been developing rapidly. Now, the financial market with Hong Kong and Shanghai as the main body has been developed, which attracts a large proportion of retail investors and international investors. Therefore, we choose the Chinese market because the information obtained from the research and analysis of the Chinese market is conducive to providing a good reference standard for the retail investors and those international investors. Consequently, the Chinese market is suitable, and it can provide a large amount of information for our empirical research.

By analyzing the sample of 2120, A-share listed firms from 2011 to 2018, we assume that retail investor attention has a supervisory effect on firms that can impact a firm's investment efficiency. The benchmark regression result shows that retail investor attention will promote the investment efficiency of any firm. At the same time, the other variables (the natural log of total assets, years of listing) have little influence on the result. Under group regression, it shows that retail investor attention has a more significant promoting effect on the investment efficiency of small market capitalization, non-stateowned, and non-Big 4 auditings. The public may pay more attention to firms with less external supervision or relatively free regulatory environments. In addition, to test whether the method is stable and reliable, we replace the measures of investment efficiency and calculate the data under different control variables. We ended up with the same result as the hypothesis.
The contribution of this paper to the existing research and literature can be divided and discussed from three aspects. Firstly, it expands the research on retail investor attention. Previous researches mainly focus on how the other factors influence the retail investor attention. For example, the impact of the financial attitude on the retail investor attention [20], or some unique stock market structures can also influence retail investor attention [21]. Even mutual fund ratings can provide valuable information for retail investors to influence their investment decisions [22]. There is simply little empirical research to analyze the effect of retail investor attention on firm investment efficiency.

Secondly, this paper also contributes to expanding some related research that focuses on firm investment efficiency. Much research has been written on the subject of retail attention, and many factors can affect firm investment efficiency. For example, the strategic business decision of the firm (corporate social responsibility level) may have an impact on the investment efficiency of the firm itself [23]. However, few studies have focused on the influence of retail investor attention on firm investment efficiency. Based on the data collected by the Baidu search engine, we find a positive relation (absolute value of the calculated results) between retail investor attention and firm investment efficiency.

Thirdly, when the retail investors face a large quantity of information about different factors related to the firm investment efficiency, their ability to choose the information will change their minds. Hao and Xiong [24] claimed that the heterogeneity beliefs towards a firm's prospect would be affected and changed by different levels of investors' information filtering levels. That will cause a fluctuation in the firm stock price (a factor that affects investment efficiency) and directly lead to firm investment efficiency. Therefore, based on the different variables such as different types of firms (if it is stateowned enterprise), different regulation environment (if Four Big auditors supervise it), we conduct an analysis on heterogeneity which focuses on the relationship between retail investor attention and firm investment efficiency. Because diverse variables could result in some problems in our research, such as the differences in regression data. Therefore, we also carry out the robustness tests to make sure the data accuracy. We find that retail investor attention potentially brings an invisible regulation to the firms, so the firms will make adjustments and improvements to promote their own development and attract investment, which will lead to an increase in firm investment efficiency.

The remainder of the paper is organized as follows. Section 2 describes the hypotheses development. Section 3 discusses data and variables. Section 4 presents the model development. Section 5 reports the empirical 
analysis. Section 6 is a robustness test, and the final section summarizes the results and offers conclusions.

\section{HYPOTHESES DEVELOPMENT}

The literature provides theories to explain the investment efficiency response to investor attention, which incorporates the idea that attention is scarce. Odean [25] and Barber and Odean [26] present a theory based on choice asymmetry. This assumes that only highprofile stocks will be bought when investors buy stocks, so increasing investor attention will increase buying. There are also points mentioned that high levels of investor attention are associated with greater sensitivity of earnings announcement returns [27], and reducing retail attention would negatively impact global stock prices. [28, 29]. We can conclude that the attention of individual investors will promote the firm's investment efficiency. According to efficient market theory, investors react quickly in the stock market based on the latest information they receive [30]. Since retail investors can require enterprises to disclose relevant information and ask companies to improve the accuracy of information disclosure $[31,32]$, retail investors play a role in social supervision. Through this method, retail investors can reduce the information asymmetry and improve the transparency of information. As the firm's stakeholders, retail investors will actively supervise the problems existing in the firm, and the firm will take appropriate internal measures to maintain good goodwill and attract the attention of retail investors, which has to promote impact on the firm's investment efficiency.

Hypothesis: Retail investor attention has a supervisory effect on firms and promotes the firm's investment efficiency.

\section{DATA AND DESCRIPTION OF VARIABLES}

\subsection{Sample selection and data sources}

This paper selects the basic data of 2120 A-share listed firms from 2011 to 2018 and the retail investor attention data from 2011 to 2019. Except for retail investor attention data from the Baidu Index website (http://index.baidu.com/) database, all other data are from the China Securities Market and Accounting Research (CSMAR) database. We exclude financial-listed companies from the sample because their balance sheets are different from those of other companies. Besides, we also exclude ST companies because their balance sheets were incredible. To eliminate the effect of the extreme values, we winsorize all continuous variables at 1 percent and 99 percent, and we got 13,991 firm-year data.

\section{2. variables}

\subsubsection{Dependent variable: firm investment efficiency}

Based on the previous experience on the used method, we adopt three different types of methodologies to measure the corporate investment efficiency, which are obtained from Richardson (2006) [33], Biddle et al. (2009) [34] and Goodman et al. (2014) [35]. First of all, the primary method used for the main regression will be INVR2 (Richardson, 2006) [33]. The equation we will use here is:

$I_{N E W, i, t}=\beta_{0}+\beta_{1}+\beta_{2}$ Leverage $_{\mathrm{i}, \mathrm{t}-1}+\beta_{3} \mathrm{Cash}_{\mathrm{i}, \mathrm{t}-1}+\beta_{4}$ Age $_{\mathrm{i}, \mathrm{t}-}$ ${ }_{1}+\beta_{5}$ Size $_{\mathrm{i}, \mathrm{t}-1}+\beta_{6}$ Stock Returns $_{\mathrm{i}, \mathrm{t}-1}+\beta_{7} \mathrm{I}_{\mathrm{NEW}, \mathrm{I}, \mathrm{t}-1}+\Sigma$ Year Indicator $+\Sigma$ Industry Indicator $+\boldsymbol{\varepsilon}_{i, t}$

Under an accounting-based framework, the total investment is divided into two parts which are investment expenditures for new projects (INEW,i,t) and maintenance investment expenditures for assets by Richardson (2006) [33]. Additionally, he also divides INEW,i,t into two parts: expected and unexpected investment, and between them, unexpected investment (Richardson) is used to measure the investment efficiency. Here, the INEW is the difference between total investment expenditure and the investment expenditure, and V/P can be calculated as the ratio of the firm's book value to its market value of equity, which represents the growth opportunities. Leverage is the par value of short-term and long-term debt minus the par value of total debt and the par value of equity. Cash is the sum of the balance of cash and short-term investments minus total assets measured at the beginning of the year. Age is the recorded number of years in which the firm has already been listed on CRSP at the beginning of the year. Size is the natural logarithm of total assets measured at the beginning of the year. Stock Returns represent the stock returns for the previous year to the investment year, and it is measured by comparing the market value between the previous year and the investment year. Year Indicator stands for a vector of dummy variables to capture the year's fixed effect. Finally, Industry Indicator is a vector of dummy variables to capture the industrial fixed effect.

Moreover, for comparison and test, we utilize two others investment efficiency measures to compare with the main regression method and conduct the stability test, which is INVB2 and INVG2, following Biddle et al. (2009) [34] and Goodman et al. (2014) [35]. The detailed information on these two methods will be shown in Appendix 1. In terms of data processing, we calculate the residuals and then take all the absolute values of the residuals. 


\subsection{2. independent variable: retail investor attention}

Most of the previous methods to measure investment efficiency focus on internal factors of the firm, such as the company strategies, and fail to find out the specific attentions of external retail investors. Moreover, with the rapid development of information technology and the Internet becoming the mainstream media, the measurement of investor attention has also changed. Following previous studies [36], we found that the retail investors' attention could affect stock price (basic index), further affecting the firm's investment efficiency. Lou [37] suggests that managers could increase their spending on advertising to attract the attention of investors. However, it is too arbitrary to measure whether the investment efficiency will be affected by advertising investment alone. Google (GSV) is one of the most commonly used indicators to measure investors' attention, which provides a lot of information. After reading the literature in the related field, Ben-Rephael, Zhi, and Israelsen [38] found that most research about investor attention is based on Google search volume. Especially in the context of COVID-19, Smales [39] demonstrated a significant correlation between global equity returns and Google statistics. The increase of retail attention will have a negative effect on stock returns. Here we choose the Chinese economic environment as the starting point, which means the retail investors will use Google and Baidu search. We finally choose Baidu search because it is the most commonly used in China (Google is not allowed normally, need VPN). It is easier for us to collect and carry-on data statistics, and the accurate frequency measures the data searched from Baidu index. Therefore, we employ the Baidu search index to measure the retail investor attention, including SVICODE and SVIALL, two data types. SVICODE represents the sum of the search data, which takes stock code as the keyword, and SVIALL stands for the sum of the search data, which takes stock code, the abbreviation of, and the full names of the companies as the key words.

\subsubsection{Control variables:}

To control the influence of other factors and make the results more robust, we introduced several control variables. We use firm size (SIZE), length of listing $(A G E)$, Book-to-market $(B M)$, return on $\operatorname{asset}(R O A)$, financial leverage $(L E V)$, return $(R E T)$, and the growth rate of operating revenue (Growth) as control variables. The definitions of the control variables are presented in Table 1.

Table 1 The name, symbol and definition of the variables

\begin{tabular}{|c|c|c|}
\hline Variables & Symbol & Definitions of variables \\
\hline Baidu search index & SVICODE & Baidu Search Index based on the firm's full name \\
\hline Baidu search index & SVIALL & $\begin{array}{l}\text { Baidu search index based on the firm's full name, firm name } \\
\text { abbreviation and firm code }\end{array}$ \\
\hline investment efficiency & INVrichardson & $\begin{array}{l}\text { use Richardson's (2006) model to measure investment } \\
\text { efficiency }\end{array}$ \\
\hline firm size & SIZE & the natural log of total assets \\
\hline length of listing & $A G E$ & years of listing \\
\hline Book-to-market & $B M$ & Market value divided by shareholders' equity \\
\hline return on asset & $R O A$ & net profit divided by total assets \\
\hline return & $R E T$ & return \\
\hline financial leverage & $L E V$ & total liabilities divided by total assets \\
\hline The growth rate of operating revenue & Growth & Growth rate of operating income \\
\hline
\end{tabular}

\section{MODEL DEVELOPMENT}

Refer to Richardson's model (2006) [33], this paper uses the deviation degree between the firm's actual investment and the predicted optimal investment level to measure the firm investment efficiency. Our regression model is as follows:

INVrichardson $_{i, t}=\alpha_{0}+\alpha_{1}$ SVICODE $_{i, t}+\alpha_{2}$ Contros $_{i, t}+\Sigma$

Ind $+\sum$ Year $+\varepsilon_{i . t}$
Where INVrichardson is firm investment efficiency; SVICODE is Baidu Search Index based on the firm's full name; Controls is control variables; $\varepsilon$ is Random error. We take the absolute value of the fitted residual in the above model as the firm's inefficient investment. The larger the absolute value of residual is, the higher the inefficient investment is and the lower the investment efficiency is. Besides, we use residual distribution value to define the two states of over-investment and underinvestment. If the residual is positive, it means overinvestment; If the residual is negative, it means under- 
investment. If Hypothesis 1 is true, it is expected that the coefficient $\alpha 1$ of SVICODE is significantly negative, indicating that investor attention has a positive impact on firm investment efficiency.

\section{EMPIRICAL ANALYSIS}

\section{1. descriptive statistics}

The descriptive statistical results of this paper are shown in Table 2. The results show that the mean of investment efficiency is 0.050 and the standard deviation is 0.053 . According to Richardson's investment model, the fluctuation of investment efficiency of the sample firms is relatively stable. The mean of the Baidu search index based on the firm's full name is 6.081, and the standard deviation is 0.563 , indicating that retail investors have a high degree of attention to China's Ashare listed firms. The financial leverage index represents the firm's debt level. The mean value of the debt level is 0.459 , and the standard deviation is 0.205 , indicating that the debt levels of firms are moderate. The mean of firms' return is -0.130 , indicating that firms are not making returns.

This table shows the descriptive statistics of investors' attention and investment efficiency. Finally, we obtain the mean, median, maximum, minimum, standard deviation, skewness, and kurtosis of main variables and control variables.

Table 2. Descriptive statistics of major variables

\begin{tabular}{|c|c|c|c|c|c|c|c|}
\hline & Mean & Median & Max & Min & SD & Skewness & Kurtosis \\
\hline INV richardson & 0.050 & 0.038 & 0.357 & 0.001 & 0.053 & 3.153 & 16.533 \\
\hline SVICODE & 6.081 & 6.027 & 7.649 & 4.983 & 0.563 & 0.436 & 2.813 \\
\hline SIZE & 22.295 & 22.123 & 26.169 & 19.723 & 1.296 & 0.654 & 3.323 \\
\hline$A G E$ & 2.843 & 2.890 & 3.434 & 1.609 & 0.350 & -1.063 & 4.390 \\
\hline$B M$ & 0.638 & 0.646 & 1.140 & 0.116 & 0.248 & -0.090 & 2.165 \\
\hline$R O A$ & 0.037 & 0.033 & 0.195 & -0.170 & 0.052 & -0.418 & 6.564 \\
\hline RET & -0.130 & -0.151 & 0.953 & -1.239 & 0.436 & 0.056 & 2.905 \\
\hline$L E V$ & 0.459 & 0.458 & 0.909 & 0.060 & 0.205 & 0.060 & 2.188 \\
\hline Growth & 0.175 & 0.100 & 3.195 & -0.542 & 0.459 & 3.910 & 24.118 \\
\hline
\end{tabular}

\section{2 benchmark regression}

The regression results of retail investor attention and firm investment efficiency are shown in Table 3. In columns (1) and (2), the regression coefficients of retail investor attention are significantly negative (-0.008), indicating that retail investor attention has a supervisory effect on firms and can improve the investment efficiency of firms. Moreover, under the condition with or without control variables, the regression coefficients of retail investor attention are significantly negative. It indicates that the control variables such as the natural log of total assets, years of listing have little influence on the results, indicating that retail investor attention will promote the investment efficiency of any firm.

Table 3. benchmark regression

\begin{tabular}{lll}
\hline & $(1)$ & $(2)$ \\
\hline SVICODE & INVrichadson & INVrichardson \\
& $-0.008^{* * * *}$ & $-0.008^{* * *}$ \\
SIZE & $(-3.611)$ & $(-3.595)$ \\
& & $-0.015^{* * *}$ \\
AGE & & $(-6.429)$ \\
& & 0.008 \\
BM & & $(0.875)$ \\
& & $-0.046 * * *$ \\
ROA & & $(-8.741)$ \\
& & $-0.052^{* * *}$ \\
RET & $(-3.036)$ \\
& & $0.007 * * *$
\end{tabular}




\begin{tabular}{lll} 
LEV & & $-0.014^{*}$ \\
& & $(-1.872)$ \\
Growth & & -0.001 \\
& & $(-0.678)$ \\
CONS & $0.107^{* * *}$ & $0.446^{* * *}$ \\
& $(7.966)$ & $(8.853)$ \\
Year fixed Effects & Yes & Yes \\
Firm Fixed Effects & Yes & Yes \\
Observations & 12551 & 12542 \\
Adj $R^{2}$ & 0.059 & 0.102 \\
\hline
\end{tabular}

\subsection{Group regression}

This paper will further explore and demonstrate the relationship between retail investor attention and firm investment efficiency. The influence of retail investor attention on the firm's investment efficiency is related to the size of the firm and the level of the ROA. Then, the influence of retail attention on the firm investment efficiency is tested in each case.

The results are shown in Table 4. Firms are grouped according to their relationship with the median, with those larger than the median being large and those smaller than the median being small. Columns (1) and (2) respectively represent small and large firm capitalization. We find that the SVICODE coefficient of the small-cap column is significantly negative, but the SVICODE coefficient of the large-cap column is not significant. It shows that retail investor attention has a more significant promoting effect on the investment efficiency of smallcap firms.

The ROA is grouped in the same way as the size of the firm, using the median. Columns (3) and (4) are based on the test of the firm's ROA. We find that the SVICODE coefficient of the low-ROA column is significantly negative, but the SVICODE coefficient of the high-ROA column is not significant. But when the ROA is low, the influence of retail investor attention on the firm investment efficiency is more significant, indicating that retail investor attention has a more significant promoting effect on firms' investment efficiency with low ROA.

Table 4: Group regression (1)

All continuous variables are winsorized at $1 \%$ and $99 \%$. Firm and year fixed effects are controlled for, and the standard errors are adjusted at the firm level. t-statistics are given in the parentheses. *, **, and *** indicate significance at the $10 \%, 5 \%$, and $1 \%$ levels, respectively.

\begin{tabular}{lllll}
\hline & $(1)$ & $(2)$ & $(3)$ & $(4)$ \\
\hline SVICODE & small-cap & large-cap & Low ROA & High ROA \\
& $-0.011^{* * *}$ & -0.002 & $-0.013^{* * *}$ & -0.002 \\
SIZE & $(-3.477)$ & $(-0.614)$ & $(-4.005)$ & $(-0.505)$ \\
& $-0.016^{* * *}$ & $-0.016^{* * *}$ & $-0.013 * * *$ & $-0.015^{* * *}$ \\
AGE & $(-4.101)$ & $(-3.925)$ & $(-3.262)$ & $(-4.693)$ \\
& $0.029^{*}$ & -0.009 & $0.030^{* * *}$ & -0.009 \\
BM & $(1.870)$ & $(-0.462)$ & $(1.969)$ & $(-0.708)$ \\
& $-0.047^{* * *}$ & $-0.033^{* * *}$ & $-0.060^{* * *}$ & $-0.032^{* * *}$ \\
ROA & $(-5.679)$ & $(-4.274)$ & $(-6.507)$ & $(-4.357)$ \\
& $-0.070^{* * *}$ & $-0.045^{* *}$ & $-0.047 *$ & -0.009 \\
RET & $(-2.876)$ & $(-1.965)$ & $(-1.796)$ & $(-0.250)$ \\
& $0.007 * * *$ & $0.006 * * *$ & $0.008 * * *$ & $0.006 * * *$ \\
LEV & $(2.769)$ & $(3.139)$ & $(3.471)$ & $(2.764)$ \\
& -0.002 & $-0.038^{* * *}$ & -0.012 & $-0.027 * *$ \\
Growth & $(-0.210)$ & $(-2.828)$ & $(-1.012)$ & $(-2.044)$ \\
& $-0.004 *$ & 0.001 & $-0.004 *$ & 0.002 \\
CONS & $(-1.699)$ & $(0.484)$ & $(-1.868)$ & $(0.906)$ \\
Year & $0.416^{* * *}$ & $0.507 * * *$ & $0.399 * * *$ & $0.438^{* * *}$ \\
& $(5.355)$ & $(4.751)$ & $(4.605)$ & $(6.302)$ \\
& Yes & Yes & Yes & Yes
\end{tabular}




\begin{tabular}{lllll}
$N$ & 6568 & 5974 & 6129 & 6413 \\
Adj $R^{2}$ & 0.084 & 0.097 & 0.132 & 0.065 \\
\hline
\end{tabular}

Table 5: Group regression (2)

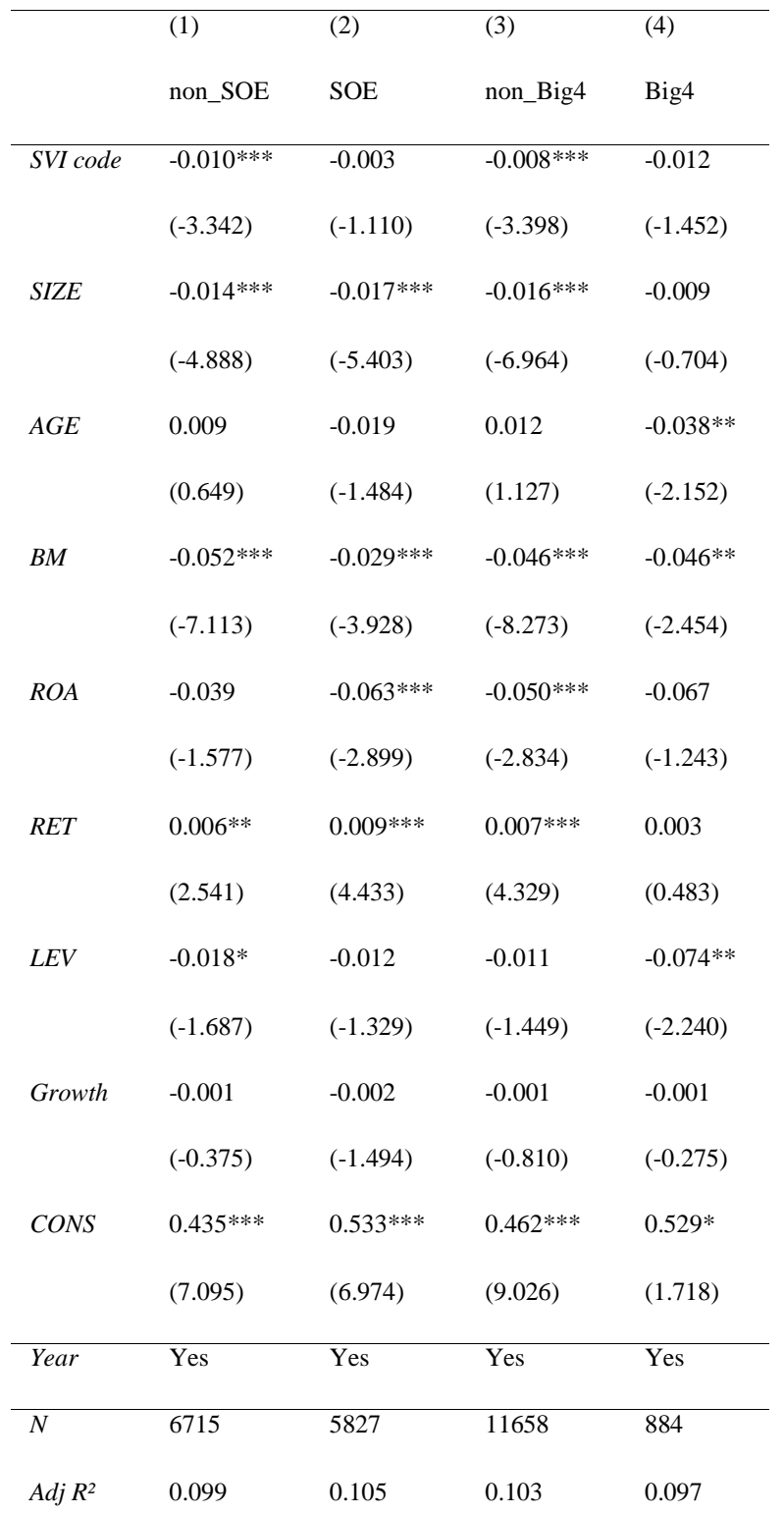

This table reports the regression results of retail investors' attention and inefficient investment, which belongs to the second group. This table focuses on two major moderating variables; the first will be whether these companies are state-owned enterprises or not; and the second one will be if these firms are audited by the
Big Four auditors (PwC, DTT, KPMG, EY). We control for the other variables the same and compare the different results under the two moderating variables.

In these four columns (1)(2)(3)(4), the regression coefficient for retail investors attention is significantly negative, which is the same as (which hypothesis), representing that the retail investors' attention can restrain the inefficient investment of firms and inhibit the investment activities of firms. Especially when the firms are not state-owned enterprises and audited by the Big Four auditors. For firms that are not state-owned enterprises, it is significantly negative at the $1 \%$ level, indicating that retail investor attention promotes the firms' investment efficiency and has a relatively significant promoting effect on non-state-owned enterprises. We can also obtain the same results for firms that are not audited by the Big Four auditors. Compared with firms audited by the Big Four, firms that the Big Four do not audit are also significantly negative at the $1 \%$ level. We speculate that the reason for such a conclusion may be that there is less external supervision of the firm under these two types of circumstances and the regulatory environment is relatively free. Therefore, the public may pay more attention to these types of firms.

\section{ROBUSTNESS TEST}

This table reports the robustness test results for the main regression, which is the equation used by Richardson (2006) [33]. Robustness tests for the main regression method (retail investors attention and investment efficiency, the model of Richardson (2006) [33]. Here we test if this method is stable and reliable. We consider the industry fixed effect, which is the endogeneity of this particular industry. Retail investors could have been considered the investment efficiency when choosing their indicators, which means a firm needs high investment efficiency. Retail investors will pay attention to it. Then we substitute different indicators (variables) of retail investors' attention to prove the stability of this method and if the data calculated by this equation is reliable. We found the results can support the (hypothesis and regression results), the conclusion is reliable.

Table 6: Robustness test (1)

\begin{tabular}{llll}
\hline & $(1)$ & $(2)$ & $(3)$ \\
& Inv_R2 & Inv_R2 & Inv_R2 \\
\hline SVI code & $-0.004 * * *$ & & \\
& $(-3.163)$ & &
\end{tabular}




\begin{tabular}{|c|c|c|c|}
\hline \multirow[t]{2}{*}{ SVI all } & & $-0.006^{* * * *}$ & $-0.003 * * *$ \\
\hline & & $(-2.999)$ & $(-3.177)$ \\
\hline \multirow[t]{2}{*}{ SIZE } & $-0.006 * * *$ & $-0.015 * * * *$ & $-0.005 * * *$ \\
\hline & $(-7.766)$ & $(-6.543)$ & $(-7.372)$ \\
\hline \multirow[t]{2}{*}{$A G E$} & -0.007 *** & 0.007 & $-0.007 * * *$ \\
\hline & $(-4.524)$ & $(0.767)$ & $(-4.932)$ \\
\hline \multirow[t]{2}{*}{$B M$} & $-0.022 * * *$ & $-0.045^{* * *}$ & $-0.023 * * *$ \\
\hline & $(-7.083)$ & $(-8.525)$ & $(-7.115)$ \\
\hline \multirow[t]{2}{*}{$R O A$} & $-0.053 * * *$ & $-0.052 * * *$ & $-0.049 * * *$ \\
\hline & $(-4.115)$ & $(-3.085)$ & $(-3.877)$ \\
\hline \multirow[t]{2}{*}{ RET } & $0.009 * * *$ & $0.007 * * *$ & $0.009 * * *$ \\
\hline & $(5.841)$ & $(4.364)$ & $(5.812)$ \\
\hline \multirow[t]{2}{*}{$L E V$} & $0.013 * * *$ & $-0.014 *$ & $0.013 * * *$ \\
\hline & $(3.537)$ & $(-1.840)$ & $(3.515)$ \\
\hline \multirow[t]{2}{*}{ Growth } & $0.004 * * *$ & -0.001 & $0.004 * * *$ \\
\hline & (2.963) & $(-0.692)$ & $(2.864)$ \\
\hline \multirow[t]{2}{*}{ CONS } & $0.236 * * *$ & $0.450 * * *$ & $0.233 * * *$ \\
\hline & (19.641) & $(8.860)$ & (19.121) \\
\hline Year & Yes & Yes & Yes \\
\hline Industry & Yes & No & Yes \\
\hline Firm Fixed Effects & No & Yes & No \\
\hline$N$ & 12542 & 12542 & 12542 \\
\hline $\operatorname{Adj} R^{2}$ & 0.085 & 0.102 & 0.086 \\
\hline
\end{tabular}

This table reports the results of the robustness tests of two other methods we have mentioned before. Robustness tests for two other models of Biddle et al. (2009) [34] and Goodman et al. (2014) [35] by changing different indicators. Here we replace the measures of investment efficiency (SVICODE and SVIALL) and calculate the data under different control variables. Then we make the comparison between these two situations, we recalculate the residual and take the absolute value and plug in the regression which we find that it is the same as the results we get before.

Table 7: Robustness test (2)

\begin{tabular}{lllll}
\hline & $(1)$ & $(2)$ & $(3)$ & $(4)$ \\
& Inv_G2 & Inv_B2 & Inv_G2 & Inv_B2 \\
\hline SVI code & $-0.009^{* * *}$ & $-0.008^{* *}$ & & \\
SVI all & $(-2.796)$ & $(-2.032)$ & & $-0.014^{* * *}$ \\
& & & $-0.011^{* * *}$ & $(-3.633)$ \\
SIZE & & $(-3.579)$ & $-0.024^{* * *}$ \\
& $-0.022^{* * *}$ & $-0.025^{* * *}$ & $-0.022^{* * *}$ & $(-5.492)$ \\
AGE & $(-6.364)$ & $(-5.676)$ & $(-6.330)$ & $0.090^{* * *}$ \\
& $0.029^{* *}$ & $0.088^{* * *}$ & $0.029^{* * *}$ & $(5.675)$ \\
BM & $(1.979)$ & $(5.501)$ & $(1.995)$ & $-0.086^{* * * *}$
\end{tabular}




\begin{tabular}{lllll}
\hline \multirow{2}{*}{ ROA } & $(-9.207)$ & $(-8.589)$ & $(-9.379)$ & $(-8.800)$ \\
& $-0.060^{* *}$ & $-0.075^{* * *}$ & $-0.061^{* *}$ & $-0.076^{* * *}$ \\
RET & $(-2.294)$ & $(-2.594)$ & $(-2.338)$ & $(-2.641)$ \\
& $0.013^{* * *}$ & $0.016^{* * *}$ & $0.013^{* * *}$ & $0.015^{* * *}$ \\
LEV & $(5.232)$ & $(5.385)$ & $(5.201)$ & $(5.256)$ \\
& $-0.020^{*}$ & -0.008 & -0.019 & -0.008 \\
Growth & $(-1.656)$ & $(-0.550)$ & $(-1.619)$ & $(-0.514)$ \\
& 0.003 & -0.001 & 0.003 & -0.001 \\
CONS & $(1.023)$ & $(-0.266)$ & $(1.044)$ & $(-0.235)$ \\
& $0.610^{* * *}$ & $0.519 * * *$ & $0.621 * * *$ & $0.537 * * *$ \\
\hline Year & $(7.492)$ & $(5.397)$ & $(7.577)$ & $(5.558)$ \\
\hline$N$ & Yes & Yes & Yes & Yes \\
Adj $R^{2}$ & 13978 & 13978 & 13978 & 13978 \\
\hline
\end{tabular}

\section{CONCLUSION}

Based on a sample of 2120 A-share listed firms from 2011 to 2018, this paper examines that retail investor attention is positively associated with a firm's investment efficiency. The empirical results show that retail investor attention has a supervisory effect on firms, promoting impact on firm's investment efficiency. In contrast, other variables have little influence on the results. Moreover, the impact of retail investor attention on a firm's investment efficiency is more pronounced in firms with lower social regulation, small market capitalization, nonstate-owned, and non-Big 4 auditings. In addition, to test whether the method is stable and reliable, we replace the measures of investment efficiency and calculate the data under different control variables. We find that it is the same as the results we got before.

To sum up, retail investors will actively supervise the firms, and firms may take appropriate internal measures to maintain good goodwill then attract the attention of retail investors, which can promote the efficiency of corporate investment.

In terms of policy inspiration, the research results of this paper show that 1) For companies they should modestly accept the feedback from external retail investors, timely supplement the missing information publicly available, and improve the level of internal supervision with the help of external regulatory forces. 2) For the regulatory authorities should set up relevant feedback departments to establish a window for the communication between retail investors and firms. After receiving the feedback from retail investors, they should timely check whether the company has any deficiencies and urge the company to solve relevant problems. 3) For retail investors, as an interested party, when they encounter the problem of missing information or doubt the accuracy of the information, they can timely feedback to the relevant departments to improve decision-making accuracy.
The other two methods are also used to estimate investment efficiency as follows. First of all, we adopt the method which is used by Biddle et al. (2009) to measure the investment efficiency, and the equations are Eqs. (3) and (4) below:

$$
\begin{aligned}
& \text { Investment }_{i, t}=\beta_{0}+\beta_{1} \text { SalesGrowth }_{i, t-1}+\boldsymbol{\varepsilon}_{i, t} \\
& \text { INVEFF }=\text { Investment }_{i, t}-E\left(\text { Investment }_{i, t}\right)=\boldsymbol{\varepsilon}_{i, t}
\end{aligned}
$$

Here Investment $t_{i, t}$ represents the amount of company i's investment in year $t$, which is defined as the net increase in tangible and intangible assets, and it needs to be scaled and calculated by lagged total assets; $\boldsymbol{\varepsilon}_{i, t}$ is the residual, and the rate of change in sales of firm $i$ from year t-2 to t-1 will be written like SalesGrowth ${ }_{i, t-1}$; N is the quantity of the observations in this research. We will be using the two-digit SIC code as industry classification to value the investment model (A) by year and industry [40]. Actually, the investment efficiency measure INVEFF (Eq. (B)) is the residual $\left(\boldsymbol{\varepsilon}_{i, t}\right)$ of Eq. (A), which shows the difference value between the real investment and the expected optimal investment from Eq. (A). The bigger the absolute value of the residuals, the lower the investment efficiency of corporations and vice versa. We will remain the "investment efficiency" name in the whole paper, although it seems that it is more suitable to note its investment inefficiency.

The second method is to utilize Goodman et al. (2014) approach to measure the investment efficiency as well. Hereunder the structure of managerial forecast quality, the expected investment and investment (in)efficiency will be estimated through the Eq. (5) :

$$
I_{i, t}=\beta_{0}+\beta_{1 i, t-1}+\beta_{2} Q_{i, t-1}+\beta_{3} C F_{i, t}+\beta_{4} I_{i, t-1}+\varepsilon_{i, t}
$$

Where $I_{i, t}$ is the investment expenditure, $i, t-1$ is the difference between the asset and previous asset (growth), $Q_{i, t-1}$ is the lagged Tobin's Q, $C F_{i, t}$ is the cash flows from operations; $\mathrm{N}$ is a range from $\mathrm{t}=1$ to 36 . 


\section{REFERENCES}

[1] Chen, S., Sun, Z., Tang, S., \& Wu, D. (2011). Government intervention and investment efficiency: Evidence from China. Journal of Corporate Finance, 17(2), 259-271. https://doi.org/10.1016/j.jcorpfin.2010.08.004

[2] Armstrong, C. S., Guay, W. R., \& Weber, J. P. (2010). The role of information and financial reporting in corporate governance and debt contracting. Journal of Accounting and Economics, 50(2), 179-234. https://doi.org/10.1016/j.jacceco.2010.10.001

[3] Sedera, D., \& Gable, G. G. (2010). Knowledge Management Competence for Enterprise System Success. Journal of Strategic Information Systems, 19(4), 296-306. https://doi.org/10.1016/j.jsis.2010.10.001

[4] Lucas, Robert E., and Edward C. Prescott. (1971). "Investment Under Uncertainty." Econometrica, Econometric Society, vol. 39(5), pages 659-681, September. Accessed May 1, 2021. doi:10.2307/1909571.

[5] Dhaliwal, D., Judd, J. S., Serfling, M., \& Shaikh, S. (2016). Customer concentration risk and the cost of equity capital. Journal of Accounting and Economics, 61(1), 23-48. https://doi.org/10.1016/j.jacceco.2015.03.005

[6] Lin, Y.-E., Li, Y.-W., Cheng, T. Y., \& Lam, K. (2021). Corporate social responsibility and investment efficiency: Does business strategy matter? International Review of Financial Analysis, 73.

https://doi.org/10.1016/j.irfa.2020.10158

[7] Yang, X., Cao, D., Andrikopoulos, P., Yang, Z., \& Bass, T. (2020). Online social networks, media supervision and investment efficiency: An empirical examination of Chinese listed firms. Technological Forecasting \& Social Change, 154. https://doi.org/10.1016/j.techfore.2020.119969

[8] Cen,W., Tong,N., \& Guo,Q. (2017). Institutional Investor Attention and Enterprise Inefficiency Investment: An Empirical Study Based on the Data of "Interactive Easy" Platform of Shenzhen Stock Exchange. Stock market guide (10), 36-44. doi: CNKI: SUN: ZQDB.0.2017-10-007.

[9] Andrei, D., \& Hasler, M. (2015). Investor Attention and Stock Market Volatility. Review of Financial Studies, 28(1), 33-72. https://doi.org/10.1093/rfs/hhu059

[10] BAKER, M., \& WURGLER, J. (2006). Investor Sentiment and the Cross-Section of Stock
Returns. Journal of Finance (WileyBlackwell), 61(4), 1645-1680. https://doi.org/10.1111/j.1540-6261.2006.00885.x

[11] Subhankar Nayak. (2010). Investor Sentiment and Corporate Bond Yield Spreads. Review of Behavioural Finance, 2(2), 59-80. https://doi.org/10.1108/19405979201000004

[12] Simon, D. P., \& Wiggins III, R. A. (2001). S\&P Futures Returns and Contrary Sentiment Indicators. Journal of Futures Markets, 21(5), 447462. https://doi.org/10.1002/fut.4

[13] Wang C. 2004. Futures Trading Activity and Predictable Foreign Exchange Market Movements [J].Journal of Banking \& Finance, 28 ( 5 ). https://doi.org/10.1016/S0378-4266(03)00047-5

[14] Bahloul, W., \& Bouri, A. (2016). Profitability of return and sentiment-based investment strategies in US futures markets. Research in International Business and Finance, 36, 254-270. https://doi.org/10.1016/j.ribaf.2015.09.007

[15] Ben-Rephael, A., Kandel, S., \& Wohl, A. (2012). Measuring investor sentiment with mutual fund flows. Journal of Financial Economics, 104(2), 363-382. https://doi.org/10.1016/j.jfineco.2010.08.018

[16] Aissia, D. B. (2014). IPO first-day returns: Skewness preference, investor sentiment and uncertainty underlying factors. Review of Financial Economics, 23(3), $148-154$ https://doi.org/10.1016/j.rfe.2014.06.001

[17] Rafael La Porta, Florencio Lopez-de-Silanes, Andrei Shleifer, \& Robert W. Vishny. (1997). Trust in Large Organizations. The American Economic Review, 87(2), 333-338.

[18] Gao, Y., Wang, Y., Wang, C., \& Liu, C. (2018). Internet attention and information asymmetry: Evidence from Qihoo 360 search data on the Chinese stock market. Physica A: Statistical Mechanics and Its Applications, 510, 802-811. https://doi.org/10.1016/j.physa.2018.07.016

[19] Xiao, J., Zhou, M., Wen, F., \& Wen, F. (2018). Asymmetric impacts of oil price uncertainty on Chinese stock returns under different market conditions: Evidence from oil volatility index. Energy $\quad$ Economics, 74, 777-786. https://doi.org/10.1016/j.eneco.2018.07.026

[20] Talwar, M., Talwar, S., Kaur, P., Tripathy, N., \& Dhir, A. (2021). Has financial attitude impacted the trading activity of retail investors during the COVID-19 pandemic? Journal of Retailing and 
Consumer

Services, 58.

https://doi.org/10.1016/j.jretconser.2020.102341

[21] Mohammad Tariqul Islam Khan, Siow-Hooi Tan, \& Lee-Lee Chong. (2017). Perception of past portfolio returns, optimism and financial decisions. Review of Behavioral Finance, 9(1), 79-98. https://doi.org/10.1108/RBF-02-2016-0005

[22] Andreas Oehler, Andreas Höfer, Matthias Horn, \& Stefan Wendt. (2018). Do mutual fund ratings provide valuable information for retail investors? Studies in Economics and Finance, 35(1), 137-152. https://doi.org/10.1108/SEF-05-2017$\underline{0120}$

[23] Lin, Y.-E., Li, Y.-W., Cheng, T. Y., \& Lam, K. (2021). Corporate social responsibility and investment efficiency: Does business strategy matter? International Review of Financial Analysis, 73.

https://doi.org/10.1016/j.irfa.2020.101585

[24] Hao, J., \& Xiong, X. (2021). Retail investor attention and firms' idiosyncratic risk: Evidence from China. International Review of Financial Analysis, 74.

https://doi.org/10.1016/j.irfa.2021.101675

[25] Terrance Odean (1999) 'Do Investors Trade Too Much?', The American Economic Review, 89(5), pp. 1279-1298. Available at: http://search.ebscohost.com/login.aspx?direct=true

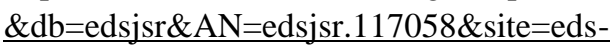
live \&scope $=$ site (Accessed: 1 June 2021).

[26] Barber, B. M., \& Odean, T. (2008). All that glitters: The effect of attention and news on the buying behavior of individual and institutional investors. The review of financial studies, 21(2), 785-818.

[27] Asher and Richardson, Vernon J. and Schmardebeck, Roy, Investor Attention and the Pricing of Earnings News (July 16, 2014). Handbook of Sentiment Analysis in Finance, Forthcoming, Available at SSRN: $\quad \underline{\text { https://ssrn.com/abstract }=2467243}$ or http://dx.doi.org/10.2139/ssrn.2467243

[28] Smales, L. A. (2021). Investor attention and global market returns during the COVID-19 crisis. International Review of Financial Analysis, 73. https://doi.org/10.1016/j.irfa.2020.101616

[29] Da, Z., Engelberg, J., \& Gao, P. (2015). The Sum of All FEARS Investor Sentiment and Asset Prices. Review of Financial Studies, 28(1), 1-32. https://doi.org/10.1093/rfs/hhu072
[30] Gur Huberman, \& Tomer Regev. (2001). Contagious Speculation and a Cure for Cancer: A Nonevent That Made Stock Prices Soar. The Journal of Finance, 56(1), 387-396.

[31] Vlastakis, N., \& Markellos, R. N. (2012). Information demand and stock market volatility. Journal of Banking and Finance, 36(6), 1808-1821.

https://doi.org/10.1016/j.jbankfin.2012.02.007

[32] Tantaopas, P., Padungsaksawasdi, C., \& Treepongkaruna, S. (2016). Attention effect via internet search intensity in Asia-Pacific stock markets. Pacific-Basin Finance Journal, 38, 107124. https://doi.org/10.1016/j.pacfin.2016.03.008

[33] Richardson, S. (2006). Over-investment of free cash flow. Review of Accounting Studies, 11(2/3), 159189. https://doi.org/10.1007/s11142-006-9012-1

[34] Biddle, G. C., Hilary, G., \& Verdi, R. S. (2009). How does financial reporting quality relate to investment efficiency?. Journal of accounting and economics, 48(2-3), 112-131.

[35] Theodore H. Goodman, Monica Neamtiu, Nemit Shroff, \& Hal D. White. (2014). Management Forecast Quality and Capital Investment Decisions. The Accounting Review, 89(1), 331-365.

[36] Wen, F., Xu, L., Ouyang, G., \& Kou, G. (2019). Retail investor attention and stock price crash risk: Evidence from China. International Review of Financial Analysis, 65. https://doi.org/10.1016/j.irfa.2019.101376

[37] Lou, D. (2014). Attracting Investor Attention through Advertising. Review of Financial Studies, 27(6), 1797-1829. https://doi.org/10.1093/rfs/hhu019

[38] Ben-Rephael, A., Zhi Da, \& Israelsen, R. D. (2017). It Depends on Where You Search: Institutional Investor Attention and Underreaction to News. Review of Financial Studies, 30(9), 3009 3047. https://doi.org/10.1093/rfs/hhx031

[39] Smales, L. A. (2021). Investor attention and global market returns during the COVID-19 crisis. International Review of Financial Analysis, 73. https://doi.org/10.1016/j.irfa.2020.101616

[40] Benlemlih, M., \& Bitar, M. (2018). Corporate Social Responsibility and Investment Efficiency. Journal of Business Ethics, 148(3), 647. https://doi.org/10.1007/s10551-016-3020-2 